\title{
The Global Concept of Sports Tourism with Emphasis on Indian Perspective
}

\author{
Dr. Kishore Mukhopadhyay
}

Associate Professor in Physical Education, Union Christian Training College, Berhampore, Murshidabad, West Bengal

To Cite this Article

Dr. Kishore Mukhopadhyay, "The Global Concept of Sports Tourism with Emphasis on Indian Perspective", International Journal for Modern Trends in Science and Technology, Vol. 07, Issue 02, February 2021, pp.-23-30.

\section{Article Info}

Received on 15-January-2021, Revised on 26-January-2021, Accepted on 01-February-2021, Published on 05-February-2021.

\section{ABSTRACT}

The attempt to define the concept of 'sports tourism' requires reference to the meaning of the basic terms, 'tourism' and 'sports'. Sports tourism is an emerging field of economic growth of a nation. Sports tourism depends upon the geographical location and also related to the sociocultural heritage of a nation. There are indeed several destinations in India offering sports tourism. There are varied sports activity that one can indulge during vacation. Distinguished adventure sports: mountaineering, rock-climbing, scuba diving, water rafting, kayaking, canoeing, sailing, surfing, water scooting. The present article critically discussed the various aspects and scope of global sports tourism as well as sports tourism of India and the future scope of sports tourism in India.

KEY WORDS: Sports, Tourism, Sports tourism and Sports Tourism Industry.

\section{INTRODUCTION}

Sport is probably as old as humanity itself. It has developed alongside the development and growth of mankind. We can hardly overestimate the meaning of sport in our lives and the day to day activities, because its main purpose is to bring up a harmoniously developed generation - a generation of strong and healthy people. Sport makes our bodies strong, quickens our reactions, and shapes the wits. It also prevents us from getting too fat, gives us valuable practice in making our eyes, brains and muscles work together and makes us more self-organized and better disciplined.

The concept of sport related tourism has become more prominent in the last few years, both as an academic field of study and an increasingly popular tourism product. The purpose of this paper is to review and critique the sport tourism literature as it stands in 1998, and to suggest a future research agenda. Disparities in the definition of sport tourism are addressed and some of the difficulties which scholars have faced in establishing a standardised definition are outlined. In answering the question why has sport tourism suddenly become so prominent, a look back at history shows that people have engaged in sport related travel for centuries. However, in the past ten years, the popularity of this form of travel has increased. Various explanations, such as the increased emphasis on health and fitness and increased use of sports events in cities to attract tourists, are examined. The question of what is known about sport tourism includes a review and critique of the literature in the three domains of sport tourism: active sport tourism, which refers to people who travel to take part in sport; event sport tourism, which refers to travel to watch a sports event; and nostalgia sport tourism, which includes visits to sports museums, famous sports venues, and sports themed cruises. The overarching conclusion from this review is that the field suffers from a lack of integration in the realms of policy, 
research, and education. At a policy level, there needs to be better coordination among agencies responsible for sport and those responsible for tourism. At a research level, more multi-disciplinary research is needed, particularly research which builds upon existing knowledge bases in both sport and tourism. In the realm of education, territorial contests between departments claiming tourism expertise and those claiming sport expertise need to be overcome (1). India has always been big in the tourism industry because of its extreme diversity. However, India's sports tourism is also carving a niche for itself in Indian tourism industry, attracting many adventurers to grab flights to India. Sports tourism in India is an absolute must for all the thrill and adventure seekers. The Historical and geographical diversities of India open up great avenues for adventure sports and activities.

India is a huge country with an extremely varied topography. Be it skiing on the great Himalayan ranges, bicycling on the wobbly Indian roads or rafting on gushing rivers - India holidays offers a range of opportunities to its visitors to test out their sporting skills! Not surprisingly, cheap flights to India are increasingly becoming more popular among sports freaks.(2)

\section{OBJECTIVES}

The objective of the study is critical discussion about the various aspects of sports tourism, global as well as Indian Scenario.Am attempt has been made to discuss the future steps to increase the sports tourism industry in India.

\section{SPORTS TOURISM}

Sports tourism, or more correctly, Sport Tourism refers to travel which involves either observing or participating in a sporting event staying apart from their usual environment. Sport tourism is a fast growing sector of the global travel industry .

The term 'Sports Tourism' basically means tourism that is based on the theme of sports. It refers to a specific travel outside the usual environment for either passive or active involvement in competitive sport. Sport is the primary reason for travel whereas the leisure element may reinforce the overall experience. Another school of thought explains it as a combination of sports activities and travel wherein it consists of two broad categories.

To understand the sport tourism herewith given some important definitions of authors, mentioned below (3).

Tourism is the impermanent go of non-resident, who utilizes different types of transport to and from a destination where distinctive effects and advantages are included for the destination (Hall, 2007).

Sport is characterized as any physical movement which is embraced at a focused or social level, where an abnormal state of physical ability is utilized with inward and outside prizes being the main forces (Coakley, 2007).

Sport tourism is the point at which an individual and/or gatherings of individuals who effectively or inactively takes an interest in aggressive or recreational sport, whilst travelling out to and/or staying in spots outside their standard surroundings and environment (Gammon and Robinson, 2003).

\section{CLASSIFICATION OF TOURISM}

There are several classifications of sport tourism. Gammon and Robinson suggested that sports tourism can be categorized as

\section{A. Hard Sports Tourism or Soft Sports Tourism,(4)}

While Gibson suggested that there are three types of sports tourism:

B. Sports Event Tourism, Celebrity and Nostalgia Sport Tourism and Active Sport Tourism(5).

The "hard" definition of sport tourism refers to the quantity of people participating at a competitive sport events. Normally these kinds of events are the motivation that attract visitors to the events. Olympic Games, FIFA World Cup, F1 Grand Prix and regional events such as NASCAR Sprint Cup Series could be described as hard sports tourism.

The "soft" definition of sport tourism is when the tourist travels to participate in recreational sporting, or signing up for leisure interests. Hiking, skiing, running(6) and canoeing can be described as soft sports tourism. Perhaps the most common form of soft sports tourism involves golf in regards to destinations in Europe and the United States. A large number of people are interested in playing some of the world's greatest and highest ranked courses, and take great pride in checking those destinations off of their list of places to visit.

Sports tourism encompasses travelling for your own sporting purposes, such as a yoga teacher training course, a badminton competition or to learn to surf. Sports tourism includes attending sporting events such as a Formula One race or a Premiership football match. Sports tourism includes nostalgic visits to places of historical importance, such as the Olympic stadium in Barcelona or to see memorabilia related to your 
favorite sporting hero, such as the museum at the Maracana football stadium in Rio de Janeiro.

C. There are, in fact, four main types of sport tourism. These types are known as:

- Sport Event Tourism

- Active Sport Tourism

- Nostalgia Sport Tourism

- Passive sports tourism

While sports tourism has not always been extremely popular, during the recent decade the amount of people attending out of area sporting events has drastically increased. People are now traveling far and wide just to attend their favorite events, and it is no wonder as to what has encouraged the sudden spike in popularity.

$D$. In the context of the above definitions, in the classification of tourism types based on the travel aim criterion, we may distinguish sports tourism, understood as a kind of tourism where the main aim is physical activity, participation in sporting events or visiting the sports facilities $(5,8)$.

Diversifying the aims of travel and the degree of physical activity undertaken by tourists (Table 1) is the reason why sports tourism cannot be treated as a homogeneous phenomenon. From the point of view of sports tourism.The tourist - participating in this type of trip may on the one hand (scale of activity) not require any special physical predisposition (visiting, observation), but on the other, it may refer to trips made by professional athletes. Including trips made by professional athletes (training, competitions), tourism travel is analogous to travel related to work as a part of business tourism (9).

Table 1. Sports tourism classification by aims of travel

\begin{tabular}{|c|c|c|}
\hline $\begin{array}{l}\text { Main aim of } \\
\text { travel }\end{array}$ & Type of tourism & $\begin{array}{l}\text { Physical } \\
\text { activity }\end{array}$ \\
\hline $\begin{array}{l}\text { Visiting } \\
\text { sports } \\
\text { facilities }\end{array}$ & $\begin{array}{l}\text { Nostalgia sports tourism } \\
\text { - Supporters' tourism } \\
\checkmark \quad \text { Ground spotting }\end{array}$ & Low \\
\hline $\begin{array}{l}\text { Travelling } \\
\text { with athletes, } \\
\text { following } \\
\text { athletes } \\
\text { (relatives, } \\
\text { idols) }\end{array}$ & $\begin{aligned} & \text { - Supporters' tourism: } \\
& \checkmark \text { Event sports } \\
& \text { tourism } \\
& \checkmark \text { Fan tourism } \\
& \checkmark \text { Groundhopping }\end{aligned}$ & \\
\hline $\begin{array}{l}\text { Amateur } \\
\text { physical } \\
\text { activity }\end{array}$ & $\begin{array}{l}\text { - Active tourism } \\
\text { - Specialist tourism } \\
\text { - Specialised tourism }\end{array}$ & \{ \\
\hline $\begin{array}{l}\text { Professional } \\
\text { physical } \\
\text { activity }\end{array}$ & - Athletes' tourism & Large \\
\hline
\end{tabular}

Source: author, based on: h.j. Gibson , Mokras-Grabowska (2015), Stasiak \& Włodarczyk $(5,9,10)$.

The large diversity, not only as regards the activities and fitness of sports tourism participants, but also the objects and subjects of their interest (facilities, events, sports teams, competitors - athletes), is the reason why it is very difficult to define the conditions of sports tourism development, related to the type of necessary infrastructure.

Trips of this kind may not require any infrastructure (e.g. swimming in a lake, climbing mountains), but they may also strongly depend on the occurrence of specific sports infrastructure (e.g. visiting stadiums, attending mass events on stadiums, arenas and sports halls).

\section{DESTINATION OF SPORTS TOURISM:}

Resource analysis represents an important first Step in the development and management of sport tourism destinations. Different destinations offer specific sport tourism experiences because they are characterized by distinct sport and tourism resources. These resources may, within the tourism sphere, relate to tourism infrastructure, levels of service development, tourist attractions and information services. The sports resource may include sports venues such as stadia and arenas, training facilities, sport science resources, and sports medicine facilities (11). Standeven and De Knop (12) recognize the considerable common interests that link the resources utilized by the sport and tourism industries. Issues of resource quality and market demand are of great relevance to sport tourism destinations. The resource requirements of a given sport differ significantly based on types of sporting pursuit, with the distinctions between amateur/ professional, novice/elite and recreational/competitive participants particularly evident. This point is well illustrated by the sport of skiing. The physical resource requirements for this sport are, essentially, skiable terrain and adequate seasonal snow cover. However, the specific resource requirement of skiers vary between the following groups:

$\checkmark$ Competing professional athletes (e.g. event management resources)

$\checkmark \quad$ Elite training athletes (e.g. sports science and sports medicine facilities)

$\checkmark \quad$ Extreme skiers (e.g. appropriate terrain) 
$\checkmark$ Recreational skiers (e.g. visitor facility development and terrain that offers appropriate levels of challenge)

$\checkmark$ Novice skiers (e.g. ski hire and ski school services)

$\checkmark \quad$ Family holiday skiers (e.g. accommodation and leisure facilities).

Thus, again, the link between a physical resource inventory and the market demands for a specific resource is evident.

Weed and Bull (2004) depicted sports tourism as a 'one of a kind connection of action, individuals and place', and accordingly it is important to think about sports tourism as a field of exploration in its own particular right. In light of this point of view to, add the exchange of the hypothetical examination of authoritative parts of sports tourism (13). Sports Tourism is a wide concept. As a rule, it alludes to the immediate and circuitous tourism advantages identified with a consumer who goes to watch and/or take an interest in wearing related exercises or occasions.

\section{ASPECTS OF SPORTS TOURISM}

Sports tourism in India is an absolute must for all the thrill and adventure seekers. The Historical and geographical diversities of India open up great avenues for adventure sports and activities. India is a huge country with an extremely varied topography. Be it skiing on the great Himalayan ranges, bicycling on the wobbly Indian roads or rafting on gushing rivers. India holidays offer a range of opportunities to its visitors to test out their sporting skills! Not surprisingly, cheap flights to India are increasingly becoming more popular among sports freaks.

Sports are an investment in the tourism industry, they Create economic growth through filled hotels, restaurants, and retail establishments. They attract high-yield visitors, especially repeaters. They Create exposure and enhances a positive image for your community. A new product is launched with a new tourism destination. It Builds community relationships and strengthens corporate support. An opportunity is created for the youth and a source of entertainment is launched. Favorable image for the destination is being generated by the development of new infrastructure. Media is being used to extend the normal communications reach (14).

According to (World Tourism Organization 1992), subsequently ratified by the UN statistical Commission in 1994 defines that tourism comprises the activities of persons travelling to and for spending some days or nights out of the environment for less than a year in purpose of leisure, holiday, business or research or any other specific purpose. In the early 1980s, Matheson and Wall (15) indicated that tourism comprised of the Short-term movement of tourists to another destination out of the regular place of living, of work and home place. Actions that need to be taken while the spending the time in such a place are facilities created to cater for the need of the tourist. (!6-19.)

The world tourism organization estimated (UNWTO, 2007) that there were 842 million international travelers in 2006 (this amount was almost 12 percent of the world's population). Among all the travelers, adventure and nature travelling is one of the fastest and youngest sectors in tourism. It creates physical and mental excitement and efforts that involve some kind of risk, real or perceived, the expectation varies depending on level of experience which may be taken as an element of physical danger. However, some of these activities may comprise of the same travelers involved in more than one journey per year and hence the precise scale of tourism as an industry is in some doubt Tens of millions of people globally work directly in the industry and many more are employed indirectly (18). Travel and transport, accommodation and catering, leisure, recreation and entertainment, promoting and developing create more employment opportunities in the tourism field. Both the demand and supply side of the destination in tourism is clear. The demand side describes the destinations as the people travel and they choose accommodation where they want to stay in order to gain experience. The supply sided of describing the destinations as the visitors know the geographical areas with their politics and government and approved for the tourism marketing and planning. The tourism products, place and the system of products always depend upon the tourism industry which affects its management. 


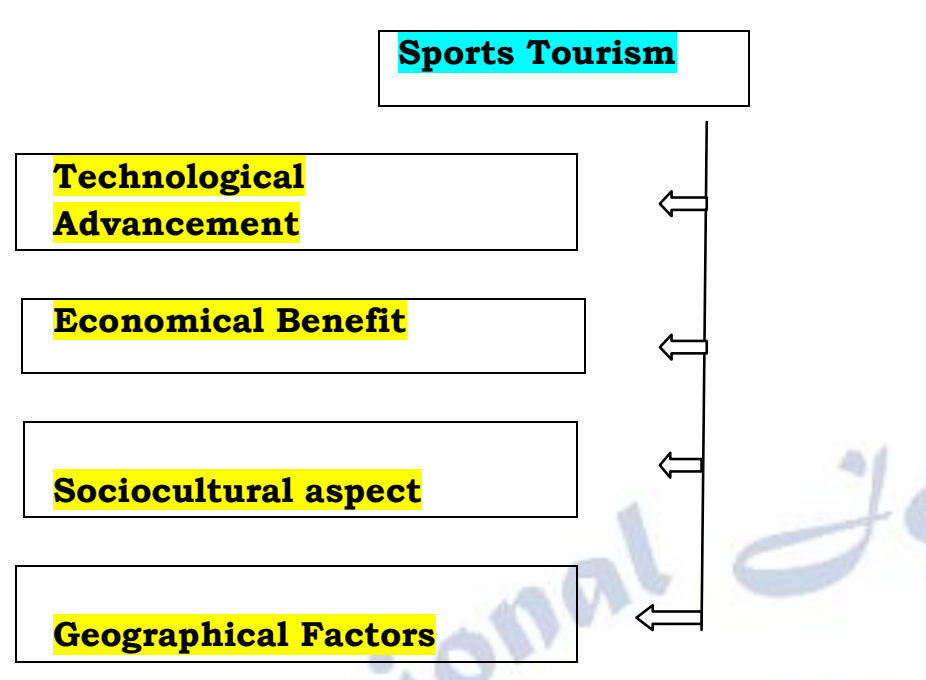

- Technological advancement in sports tourism : Due to the development of science and technology the scope of sports tourism expands tremendously. The availability of transportation creates the scope of scheduling the leisure time for outdoor activities easily. Availability and development of the luxury hotel industry provide the ample opportunity to stay any place easily. The television and social network provides the various sports related enjoyable activities in a befitting manner.

Because of the wide range of technological innovations, the opening of travel and appeal of sport has greatly increased, allowing for the rapid expansion of sport tourism. More specifically, increased access, expanded availability, and ease of participation has contributed to the increased rise in popularity of sport tourism.

- Economic benefit of sport tourism: Sport and tourism each contribute a great deal to the global economy and have become an element in the armory of politicians, planners and economists seeking to regenerate local economies. As a combination of the two, sport tourism has a significant economic impact. In order for people to participate in any form of sport tourism, an adequate amount of money must be possessed. The affluence of families today has risen to new heights, mainly because of major changes in the type of jobs people are employed in, as well as how people work. Similarly, people are experiencing an increase in the amount of leisure time available for sport tourism activities. New job opportunities are increasing due to the increase sports tourism globally as well as India.

- Sociocultural aspects of sports tourism: The trend to increase sport touristic experiences and to provide them in faraway, often very different cultures simply increase the importance of addressing both the potential positive and the negative sociocultural impacts of sport tourism. By intermixing with the people of various cultures the socialization bonding is increasing which in turn increases the unity among the diversity.

- Geographical factors: Depending upon the geographical location and facilities the sports tourism industry is growing, e.g. for ice skating, mountaineering, scuba diving, paragliding different kind of environment and atmosphere is highly required which is based on the different geographical locations.

\section{Sports Tourism in Indian Scenario}

Sports tourism is broadly defined by the adventure sports and game in India. There are indeed several destinations in India offering sports tourism. There are varied sports activities that one can indulge during their vacation.

Sports tourism is witnessing 10-12 per cent growth as Indians are showing more enthusiasm for visiting a country to attend sporting event, according to industry experts.

"Globally sports tourism is a multi-billion dollar industry. According to estimates, global sports tourism was worth USD 7 billion in 2017. While it is a mature industry overseas, in India it is in infancy (stage)," Cox and Kings Head, relationships, Karan Anand told here. The first love for Indians is cricket and they travel to watch the game, whether in India or overseas, he added.

"There has also been a shift in the interest for other sporting events like the Soccer World Cup or the Olympics. We see 10-12 per cent growth in arrivals to these destinations, when a major sporting event takes place," he said.

"Many people use these trips as an excuse for a longer holiday, combining their sporting passions with a general love for travel. On the other side, many in the tourism industry have also begun to realise the value of wooing these tourists - many of them fall into the high-spending category, stay longer than other tourist categories, are high-caliber and often stimulates other tourism," he added (20).

Types of adventure sports: Distinguished adventure sports: mountaineering, rock-climbing, scuba diving, water rafting, kayaking, canoeing, sailing, surfing, water scooting. Aero sports like: ballooning, paragliding, hand gliding. These sports 
offer scope for sports lover and enthusiasts from the entire world.

Adventure hot sports in India: Goa, Andaman and Nicobar, Kerala, Uttaranchal, Rajasthan, Andhra Pradesh, Tamil Nadu, Jammu and Kashmir, Assam, Sikkim, Lakshadweep.

\section{Outbound Sports Tourism in India}

A holiday with friends or family to witness a mega sporting event is no longer an alien concept for Indian travellers. Today, sporting enthusiasts in India are willing to spend 'top dollar' to jet set across the globe to experience the thrill of watching their favourite game live. These fans also like to 'live it up' exploring and enjoying the destination simultaneously.

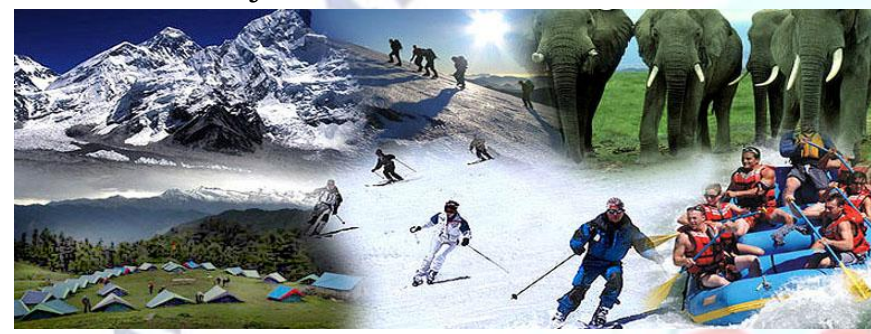

Fig-1. Different Sports Tourism related places in India

Sports tourism attractions are destinations that provide the tourist with things to see and do related to sport. Attractions can be natural (parks, mountains, wildlife) or manmade (museums, stadiums, stores). General characteristics represented in this core area of sports tourism include visits to:

- state-of-the-art sports facilities and/or unique sports facilities that generally house sporting events, such as stadiums, arenas and domes;

- sports museums and hall/walls of fame dedicated to sports heritage and to honoring sports heroes and leaders;

- sport theme parks including water parks, summer skijumps, bungee jumping;

- hiking trails developed for exploring nature;

- sports retail stores.

Sports tourism resorts are well-planned and integrated resort complexes with sports or health as their primary focus and marketing strategy. In many situations, these vacation centers offer high-quality facilities and services to the sport tourist.

\section{General Benefits of Sport Tourism}

- Sports are an investment in the tourism industry.

- Creates economic growth through filled hotels, restaurants and retail establishments.
- Creates new product, a new tourism destination.

- Maximizes facility use in your community.

- Builds community relationships and strengthens corporate support.

- Creates youth opportunity/entertainment.

- Generate favorable image for the destination.

- Develop new infrastructure.

- Use the media to extend the normal communications reach.

- Generate increased rate of tourism growth or a higher demand plateau.

- Improve the organizational, marketing, and bidding capability of the community.

- Secure a financial legacy for management of new sport facilities.

- Increase community support for sport and sport-events.

- Increase Job opportunities

- Health benefit

- Mental refreshment

- Economical growth of the nation.

\section{Future of Sports Tourism in India:}

Scope and future of sports tourism is endless in India because of its diverse topography and climatic condition. You can enjoy on land and water, under water and in air whatsoever form of adventure sports in India. The future of sports tourism and adventure sports in India is very bright.

Business tour combined with active sports is becoming highly popular where business meets leisure and such kind of sports tourism on business tour is global cooperate strategy for employee entertainment and well being. Moreover, sports tourism is nurtured by professional sports person they have to travel extensively for their carrier to participate in national and international championship like the Cricket World Cup, Soccer World Cup, Wimbledon so on and forth. Commonwealth Games 2010, Delhi is the best example of sports tourism.

Certain facts can consider for the promotion of sports tourism industry in India, as follows (21):

- Facility models : In many cases there are multiple stakeholders with different goals, so it's important we bring those groups together and cast a vision for how the balance is going to work. We can operate and build a business model, however, those stakeholders want, so 
what is important to us is understanding all of the objectives, gaining buy-in and achieving alignment. From there it's really about building a business and operating model for achieving those objectives and goals.

- Measuring ROI : Currently, a majority of sports tourism venues are primarily measured by their economic impact numbers with some emphasis on their bottom line," said Clement. "This is really only measuring a portion of the total impact of a facility. A shift in measuring the total impact is important because it is directly related to the amount of funding a project can justify, including the continued investment into these assets."

New tools are emerging to do just that. There is an increased need to quantify the effects of sports, parks, and green space, particularly in the parks and recreation market.

As facility designs shift into a hybrid of community recreation and sports tourism, tools like these will help justify the initial capital investment and take a more wholistic view of the benefits of these assets

- Access for all: Sports tourism relies on the spending of thousands of parents willing to invest in their children through private lessons, club team fees, airline tickets, hotel rooms, and countless weekends on the road. Whether for hopes of college scholarships or just for the exceptional experience and life lessons learned through sports, these parents utilize their expendable dollars on this type of recreation. The data and trends suggest sports tourism will continue to expand with more families making the investment. Unfortunately, not everyone can pay to play, a major contributing factor to the obesity and physical inactivity pandemic

- Technology : Smart court surfaces, live-streaming, game apps and management tools are helping facilities, event owners, and coaches create a better experience for visitors and the community. The technology is progressing rapidly, and it's going to provide a better way to serve the player and spectator.

- Need for the network : "We think there is no shortage of growth in the participatory sports environment," Clement added. "If there is an economic downturn, the previous cycle demonstrated that most families are not going to cut out their kids sport experience because there is so much value in providing that opportunity."
The concept behind the national network is centered around pairing the best venues and destinations with the best event service providers, vendors and staffing. That is what sets SFM Network apart, the ability to build a platform of the largest and fastest growing sports tourism venues in the country, understanding their unique draws to compliment one another, and designed with unequaled on-the-ground services while still gaining the benefit of shared operational efficiencies.

\section{CONCLUSION:}

The growing diversity of types of tourism, which can be defined as sports tourism, their rapidly growing popularity (e.g. marathons, hiking, trips of the groundspotting and groundhopping type) reflects the changes/ transformations taking place in the style of living of contemporary societies, increasingly oriented towards physical activity. Adding tourism development forecasts (Tourism towards 2030), we may expect further growth in sports tourism in the near future, both in the quantitative and qualitative sense (an increasing number of participants and a growing diversity of forms, respectively). The present article discussed the various scopes of sports tourism industry as well as new job opportunities for the youth and the development of the economy of the nation in parity with the technological innovations.

\section{REFERANCES}

[1] Heather J. Gibson is with The University of Florida, Center for Tourism Research and Development, Department of Recreation, Parks and Tourism, 304 FLG, P.O. Box 118209 Gainesville, FL 32611-8209, USA.

[2] http://www.icec-council.org/wp-content/uploads/2016/ 02/Sports-Tourism-in-India.pdf

[3] Raghu Ankathi, A Critical Research on factors affecting sports tourism in India, IJARIIE, Vol-1 Issue-5 2015.

[4] Gammon, Sean; Robinson, Tom (2003). "Sport and Tourism: A Conceptual Framework". Journal of Sport Tourism. 8 (1): 21-26. doi:10.1080/14775080306236.

[5] Gibson, Heather J. (1 April 1998). "Active Sport Tourism: Who Participates?". Leisure Studies. 17 (2): 155-170. doi:10.1080/026143698375213.

[6] "What's a Running Tour? Frequently Asked Questions 360RunningBarcelona". 360runningbarcelona.com. Retrieved 2018-02-19.

[7] https://tourismteacher.com/sports-tourism/

[8] ROSS D., 2001, Developing Sports Tourism. A Guide for Destination Marketers and sports Events Planners, National Laboratory for Tourism and eCommerce. University of Ilinois at Urbana Champaign, http://www.lib.teiher.gr/webnotes/sdo/Sport\%20 Tourism/Sport-Tourism\%20Development\%20Guide.pdf; 8.04.2016 
[9] STASIAK A., WŁODARCZYK B., 2015, Czy turystyka może nie być aktywna? O potrzebie podziałów, [in:] Wczoraj, dziś i jutroturystyki aktywnej i specjalistycznej, A. Stasiak, J. Śledzińska, B. Włodarczyk (eds.), Wyd. PTTK „Kraj”, Warszawa, pp. 39-51.

[10] MOKRAS-GRABOWSKA J., 2015, Turystyka aktywna zagadnienia terminologiczne i klasyfikacje, [in:] Wczoraj, dziś i jutro turystyki aktywnej i specjalistycznej, A. Stasiak, J. Śledzińska, B. Włodarczyk (eds.), PTTK „Kraj”, Warszawa, pp. 11-25.

[11] Maier, J. and Weber, W. (1993). Sport tourism in local and regional planning. Tourism Recreation Research, 18(2), 33-43.

[12] Standeven, J. and De Knop, P. (1999). Sport Tourism. Champaign, IL: Human Kinetics.

[13] Weed, M., \& Bull, C. (2004). Sports Tourism. Participants, Policy and Providers. Amsterdam: Elsevier Butterworth-Heinemann.

[14] Josephin Arulmozhi S and Vinayagamoorthi Gomathinayagam, MARKETING SPORT TOURISM IN INDIA, International Journal of Advance and Innovative Research, Volume 6, Issue 2 (XXXV) : April - June, 2019.

[15] https://thediplomat.com/2016/07/indias-growing-sports -industry/

[16] https://www.tourism-review.com/travel-tourism-magazin e-sports-tourism-worldwide-phenomenonarticle 1330

[17] https://economictimes.indiatimes.com/industry/services / travel/sports-tourism-industry-in-india-sees-10-12-per-c ent-growth-experts/articleshow/64147347.cms

[18] https://journal.lib.uoguelph.ca/index.php/rasaala/articl e/download/3152/3364

[19] https://experts.illinois.edu/en/publications/marketing-s port-tourism-creating-synergy-between-sport-anddestin

[20] https://economictimes.indiatimes.com/industry/services / travel/sports-tourism-industry-in-india-sees-10-12-per-c ent-growth-experts/articleshow/64147347.cms?from=md $r$

[21] https://sportsplanningguide.com/the-future-of-sports-to urism/ 